\title{
Dançando cacofonias: de mestiços, inã (Karajá) e "cultura"
}

Dançando cacofonias: de mestiços, inã (karajá) e "cultura"

\section{Helena Schiel}

\section{(2) OpenEdition}

1 Journals

Edição electrónica

URL: https://journals.openedition.org/aa/2477

DOI: $10.4000 /$ aa. 2477

ISSN: 2357-738X

\section{Editora}

Programa de Pós-Graduação em Antropologia Social (UnB)

\section{Edição impressa}

Data de publição: 1 dezembro 2017

Paginação: 353-381

ISSN: 0102-4302

\section{Refêrencia eletrónica}

Helena Schiel, «Dançando cacofonias: de mestiços, inã (Karajá) e "cultura"», Anuário Antropológico [Online], v.42 n.2 | 2017, posto online no dia 12 junho 2018, consultado o 18 maio 2021. URL: http:// journals.openedition.org/aa/2477 ; DOI: https://doi.org/10.4000/aa.2477

\section{(c) $)(9)$}

Anuário Antropológico is licensed under a Creative Commons Atribuição-Uso Não-Comercial-Proibição de realização de Obras Derivadas 4.0 International. 


\section{Dançando cacofonias: de mestiços, inã (Karajá) e "cultura"}

Helena Schiel

UFOPA

O presente artigo nasceu de uma proposta de reflexão a respeito dos efeitos da "urbanização" sobre grupos étnicos. ${ }^{1}$ Pesquisando entre os Karajá havia vários anos, acreditei pertinente me propor, naquela ocasiáo, a abordar em termos comparativos os contextos etnográficos das aldeias que formam as duas extremidades de seu território. São eles a aldeia Buridina, em Aruanã (mais ao sul), e as aldeias dos Xambioá (mais ao norte).

Diante de distintas histórias de convívio com a populaçáo não índia, e tendo conhecido diferentes experiências com a vida na cidade e pertencentes a distintos grupos ina $\tilde{a}^{2}$ essas aldeias me pareciam ter chegado a resultados bastante semelhantes. A partir de grupos locais que foram completamente desmembrados nos anos 40 do século XX, a aldeia Xambioá, a mais setentrional, foi constituída após a experiência urbana de seus habitantes. No outro extremo, e a partir de uma momentânea dispersão de seus habitantes, a aldeia Buridina, a mais meridional, foi reconstituída em meio a uma cidade, Aruanã, no estado de Goiás.

Nas páginas que seguem, abordarei o fenômeno do surgimento de uma categoria identitária, a do "mestiço", a partir da experiência urbana destes dois grupos inã. As preocupaçôes iniciais com urbanizaçâo e cidadania deram lugar a uma abordagem mais centrada nesta categoria de mestiço, presente nos dois contextos etnográficos. Dessa forma, tanto a recepção de dádivas dos brancos na forma de "serviços" como política indigenista quanto as categorias identitárias que surgem ao longo do processo de sua convivência urbana tentarão ser explicadas à luz da interpretação inã desses fenômenos. ${ }^{3}$ Utilizo o termo "interpretação" em seu sentido forte: a maneira como esses grupos inã metaforizam e enunciam as consequências dessa experiência de aproximadamente um século.

As abordagens de situaçóes sociais tais como vivenciam os Karajá de Buridina e os Xambioá do Baixo Araguaia animaram o debate antropológico no Brasil desde, pelo menos, os anos 1950. Dos estudos que enfatizavam o que se convencionou chamar de "aculturação" (Schaden, 1969), em geral atribuindo aos grupos uma "perda" cultural, passou-se a enfatizar um processo inexorável de integração à sociedade nacional brasileira. É o que sugere o cromatismo da tipologia de "graus de contato" com a sociedade nacional, de Darcy Ribeiro (1970). Tais abordagens 
pareciam insuficientes em suas tipologias muito baseadas em traços "culturais". Diante da inegável assimetria do "contato", Roberto Cardoso de Oliveira cunhou o conceito de "fricção interétnica" e conduziu pesquisas que levem em conta tal assimetria (Cardoso de Oliveira 1972, 1978).

A partir dos anos 1980 e ganhando força nos anos 1990, os movimentos indígenas passaram cada vez mais a participar ativamente, no cenário nacional, do processo político que os envolvia. Tal como o resumiu Bruce Albert, passam de "uma 'resistência especulativa' (discurso sobre o outro para si) à 'adaptação resistente' (discurso sobre si para o outro): de um discurso cosmológico sobre a alteridade a um discurso político sobre a etnicidade" (2002:242). O movimento teórico que parte de uma chave "cultural" (representado por Darcy Ribeiro ou Egon Schaden, por exemplo) para uma chave mais social parece insuficiente quando as reivindicaçóes políticas indígenas passam a fundir os dois campos. Como menciona Eduardo Nunes em revisão recente deste debate,

como isolar "sociedade" de "cultura" quando discursos indígenas estão fazendo críticas potentes a questôes de relevância global, como a preservaçáo ambiental, a partir de um prisma xamânico [...]? Como fazê-lo quando eles começam a requerer de seus parceiros, não mais recursos sócio-políticos não-indígenas (como demarcação de terras ou escolarização), mas possibilidades de melhor desenvolver capital sócio-cósmico (2012:287)

De certa forma, não há mais sentido em falar em situaçóes de "contato interétnico", como se fazia nos anos 1960 ou 1970. Se a situação isolada ideal jamais existiu, tampouco os indígenas foram integrados à sociedade nacional a ponto de perder sua distintividade, ou desapareceram pela violência e doenças, como faziam supor os vaticínios de então.

Casos análogos aos abordados aqui - os de grupos indígenas em cidades (ou urbanos, ou que tenham passado por experiências urbanas) - foram abordados recentemente por etnografias como as de Cesar Gordon (2006), Geraldo Andrello (2006) ou Cristiane Lasmar (2005). A relaçâo de um grupo karajá e javaé com um "espaço urbano" que torna a ser plenamente indígena foi descrita por Oiara Bonilla (2000) em sua dissertação de mestrado. Nesse trabalho, a autora descreve o processo de desintrusão da aldeia Porto Txuiri, dentro da Ilha do Bananal. Ela havia sido ocupada por náo índios e nomeada Porto Piauí. Por outro lado, Patrícia Rodrigues, numa análise centrada no gênero e na corporalidade, mostra que o poder criativo e perigoso dos brancos está associado ao mesmo conjunto de referências que o ligam ao feminino: 
o poder da transformação e da criaçáo é um poder extraordinário associado ao feminino [...]. Não por acaso, é o mesmo tipo de poder que é atribuído aos brancos, por meio da associaçáo que é feita entre os ossos femininos e as armas de fogo: a tecnologia é fruto de uma grande criatividade e é um poder extraordinário que se desejam mas ao mesmo tempo é opressora e temida, por ser mortal (Rodrigues, 2005:133).

Finalmente, os trabalhos de Eduardo Nunes $(2009,2012)$ abordaram justamente a aldeia Buridina. $\mathrm{O}$ autor aprofundou largamente minhas iniciais sugestóes a respeito do surgimento da categoria mestiço naquele contexto etnográfico.

A abordagem que se segue está centrada sobretudo nas reflexôes indígenas sobre a categoria mestiço e, subsidiariamente, nas suas consequências em termos de acesso a serviços da política indigenista. Não faz parte de minha pretensão aprofundar o debate teórico em torno da temática índios urbanos ou contato, mas trazer evidências etnográficas sobre as reflexóes indígenas sobre essa categoria, mestiço, fruto da experiência extensiva com os náo índios dos dois extremos do território inã. Meus dados não permitem abordar os pertinentes temas da corporalidade, explorados pelas etnografias de Nunes (2012) e Rodrigues (1993, 2008).

\section{Histórias de coisas e mestiços}

Entre 1847 e 1848, Rufino Teotonio Segurado, um deputado da Assembleia Legislativa de Goiás, empreendeu uma expedição pela qual subiu o Rio Araguaia, a partir do Pará, na tentativa de atestar sua navegabilidade. Naquela viagem, estabeleceu contatos pacíficos com algumas aldeias karajás, cuja mão de obra tencionava utilizar para a navegação fluvial, "no que são mui hábeis". Movendose com o auxílio de intérpretes, Segurado inquiria a respeito da disposição de alguns Karajá sobre a possível instalação de estabelecimentos para a colonização, nas vizinhanças de suas aldeias. Perguntou a um cacique se ele gostaria que se instaurassem os "presídios" (instalaçôes militares) ao longo do rio, ao que o cacique Carô respondeu que sim, que para ele isso seria muito bom. Rufino Segurado insistiu, explicando que isso significaria trazer vacas e cavalos. Carô confirmou que seria muito bom. Reiterou ainda Segurado que isso implicaria também trazer missionários; e o cacique Carô respondeu da mesma maneira, não sem se pôr, desta feita, profundamente pensativo por algum tempo. Repentinamente, o cacique Carô levantou a cabeça e perguntou: "presídio também?" "Presídio também." Então, com vivacidade e com a voz grossa, o cacique disse: "presídio não, não quero. Padre não, tori não, boi não, cavalo não. Eu não quero" (Segurado, 1848:194). ${ }^{4}$ 
Esse episódio foi reproduzido pela etnografia de Georges Donahue (1982) com a intenção de mostrar o quão ambígua seria a relação dos Karajá com as levas de colonização que vinham ocupando suas terras. Entre as primeiras indagaçôes do cacique Carô àquele visitante, logo que se encontram, e antes mesmo do diálogo acima reproduzido, registrou-se a pergunta sobre quando iriam retornar os missionários, que sempre traziam presentes. Para Donahue, os Karajá pareciam querer os bens dos tori (não índios), mas não os seus intermediários. Além disso, o episódio sugere a propensão dos colonizadores a se instalar nas cercanias de aldeias.

Por seu lado, os povos inã têm também sua maneira de contar a história dessa ocupação.5 "Tio Jacinto dizia assim: que a cidade estava crescendo e que daqui a pouco a gente ia estar cercado, igual a porco no chiqueiro", relembra Kari. Para ela, o tio Jacinto tinha razão: "o pior é que tudo o que ele dizia está acontecendo!" A aldeia é rodeada, por um lado, pelo Araguaia; ao fundo (à jusante), um muro a separa de um porto e um guarda-barcos. Os outros lados do perímetro são delimitados por uma cerca, ora de alambrado, ora de arame farpado, que a separa de ruas, um muro de escola e uma avenida da cidade. Essa é Buridina, a aldeia mais ao sul do território karajá. Kari nasceu e morou a maior parte de sua vida nesta aldeia, contígua à cidade de Aruaná, oeste do estado de Goiás. Aruanã, antiga Santa Leopoldina, porto de onde saiu a maior parte das expediçóes que exploraram o Rio Araguaia, atual balneário turístico do interior do Brasil.

Centenas de quilômetros ao norte, descendo aquele mesmo rio, algumas palavras dos antigos parecem ecoar. Dalva, ao recordar os primeiros casamentos que se deram com os tori (náo índios), evoca as palavras de seu avô, por quem foi criada. Manuel Achurê admoestava os filhos e netos para que não se casassem com os tori, "porque vai chegar um momento em que vocês não vão mais saber falar a língua, não vão reconhecer família, vão acabar virando tori”. Manuel Achurê foi um dos derradeiros grandes caciques xambioás: um dos responsáveis por sua reunificação, nos anos 1950. Dalva se admira em, de certa forma, reconhecer na atualidade a profecia de seu avô: "do jeitinho que ele disse, está acontecendo mesmo! Parece que esses velhos enxergavam melhor as coisas..."

Os Karajá têm habitado as margens do Rio Araguaia desde os tempos mais remotos de que têm lembrança. A um movimento ascensional cosmogônico, ${ }^{6}$ eles acrescentaram um movimento migratório na direção montante do Araguaia. Segundo o que é relatado em sua crônica oral, o território tradicional estendiase para muito além do atual. $\mathrm{Na}$ altura da cidade de Aruanã, as águas do Rio Vermelho encontram as águas araguaias. As aldeias karajás subiriam esse rio até a atual cidade goiana de Britânia, ${ }^{7}$ limite máximo da expansão territorial karajá. Ainda segundo eles, a ocupação não prosseguiu o curso montante do Rio Araguaia 
pelo temor inspirado pelos Xavante que ali habitavam, dando-se preferência ao Rio Vermelho. No extremo setentrional do território, as aldeias se estendiam praticamente até o encontro das águas araguaias com as águas do Rio Tocantins, na formação hoje conhecida como "Bico do Papagaio", o extremo norte do atual estado de Tocantins.

Figura 1 Mapa da região do Araguaia indicando cidades e aldeias karajá

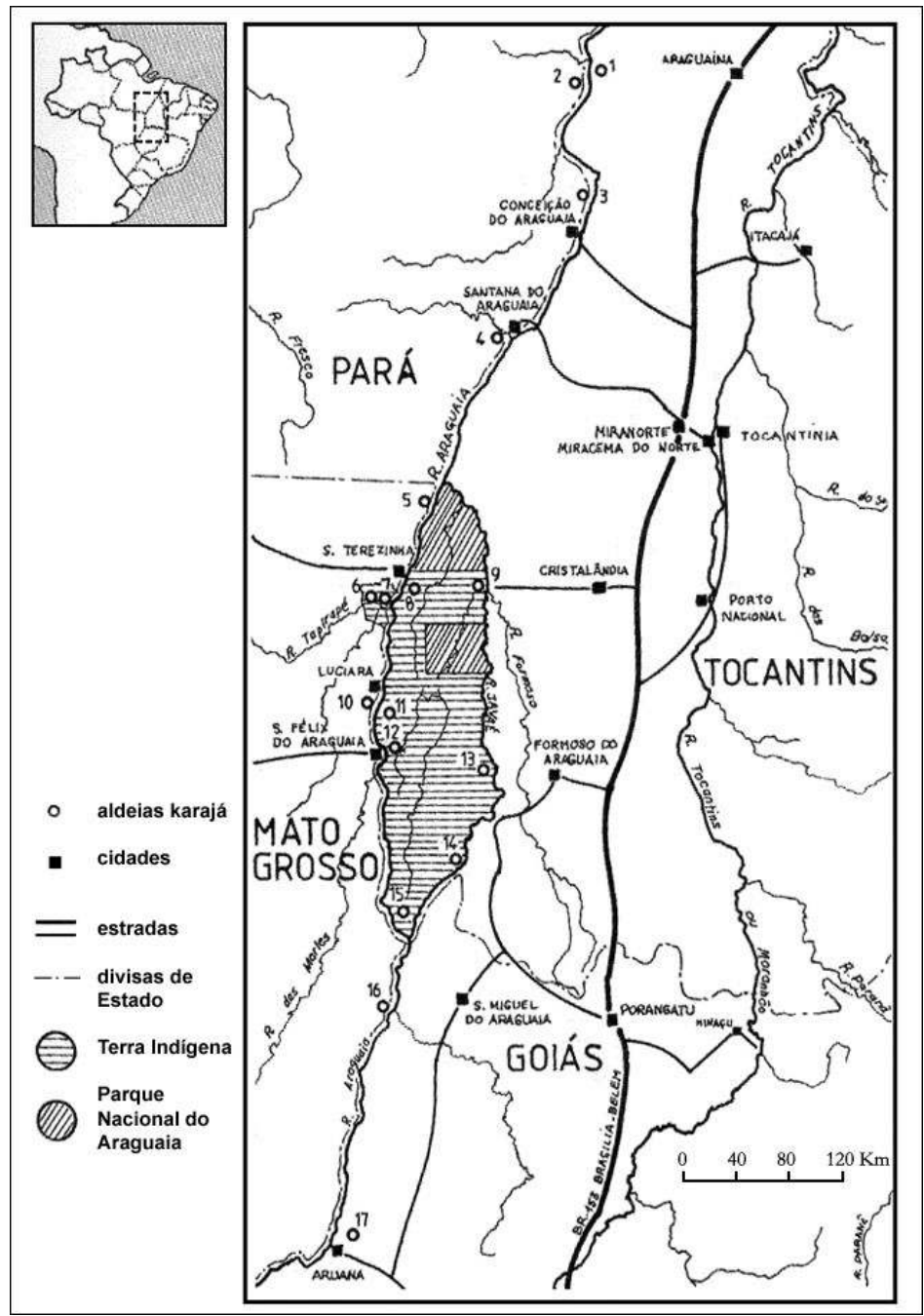

Fonte: Pétesch (2000)

Em 1842, Francis Castelnau desceu o rio e alcançou as aldeias xambioás. Seu cálculo levou à cifra de 2.300 habitantes (Castelnau, 1949). Posteriormente, Paul Ehrenreich, em sua expedição de 1888, relatou que os Xambioá seriam o grupo 
mais numeroso. ${ }^{8}$ Ehrenreich (1948) falou em quatro grandes aldeias, pelo que estimamos 200 habitantes por aldeia, chegando à cifra de 800 pessoas.

Em 1850, no encontro dos rios Vermelho e Araguaia, fundou-se o povoado de Santa Leopoldina, com a instalação de um presidio. Em uma expedição em 1862, o general Couto de Magalháes constatou que o povoado contava com 30 casas. Quando presidia a província de Goiás, Couto de Magalhães buscou transferir a capital de Vila Boa de Goiás para Santa Leopoldina (futura Aruanã), a fim de escoar a incipiente produção agrícola da região para o porto de Belém, no Pará. A despeito das disposiçôes do general, Santa Leopoldina não apenas não veio a se tornar capital como se manteve atrelada à cidade de Goiás até meados do século XX.

$\mathrm{Na}$ mesma época em que estava sendo fundada a cidade de Leopoldina, o geógrafo e naturalista francês Henri Coudreau subiu o Rio Araguaia, partindo de Belém do Pará. Ele relatou a existência de dez aldeias Xambioá (Coudreau, 1897), que estariam em permanente estado de animosidade contra os Kayapó. 'Grupo numeroso e reputado como "feroz" pelos integrantes da expedição de Castelnau, os Xambioá conheceram um drástico declínio populacional em apenas sessenta anos, isto é, entre a estatística de Ehrenreich e a visita do primeiro inspetor do Serviço de Proteção ao Índio (SPI), como tentativa de ali estabelecer um posto. O censo do inspetor do SPI, Dorival Nunes, indicou em 1943 a existência de apenas duas aldeias reduzidas: a do capitáo Manuel Achurê e a do capitão Tchekó, somando 45 pessoas, entre adultos e crianças.

Uma das habitantes mais velhas das aldeias xambioás, Luzia Kolyty, se recorda desse período. Segundo Kolyty, as aldeias se situavam em margens opostas do rio, relativamente próximas. Havia uma disputa de prestígio entre os caciques de cada uma. Pouco após a visita do inspetor do SPI, um episódio terminou por dissolver as derradeiras aldeias xambioás. Uma morte foi seguida de uma acusação de feitiçaria e, consequentemente, os remanescentes xambioás se dispersam pelas cidades da região. É preciso fazer notar que um dos impactos da expansão da colonização do vale do Araguaia são as epidemias de doenças desconhecidas dos povos indígenas da regiáo. Pode ser que esse episódio tenha sido consequência de uma dessas epidemias. Soa estranho que a populaçáo inã mais numerosa no final do século XX seja a que quase desapareceu 60 anos depois. ${ }^{10}$

Não há como precisar quanto tempo durou esta total dispersão dos Xambioá. Dez anos? Quinze anos? O suficiente para que crianças na época da dispersão fossem jovens adultos no tempo da reunificação. Posteriormente, o inspetor do SPI que havia realizado o censo de 1943 instalaria um posto num local próximo às últimas aldeias xambioás. Ergueu uma casa, plantou uma roça e saiu em busca 
dos remanescentes xambioás. A primeira família a retornar foi a de Luzia Kolyty. Lawari recorda que o pai soubera que o SPI estava tentando juntar novamente os Xambioá e, decidido a retornar, roubou uma canoa em Conceição do Araguaia. Desceu o rio noite adentro, remando de volta ao iraru mahádu, o povo de baixo.

Um movimento semelhante vamos observar entre os Karajá de Buridina, com uma diferença temporal de aproximadamente trinta anos. Herbert Baldus fez uma descrição da aldeia, em 1947, que correspondia exatamente à localização atual (Baldus, 1948). A aldeia estaria separada de Leopoldina apenas por um pequeno córrego. Sugeriu, ademais, que se removesse a aldeia para outro local, para afastá-la da cidade.

Nos anos 1940, Buridina já era uma aldeia estabelecida, contígua à cidade de Aruanã. As pessoas mais velhas da aldeia que se definiam como originais dali nasceram provavelmente nesta época. Nos anos de 1960 e 1970, a população já estava bastante reduzida. Tal como entre os Xambioá, um episódio de acusação de feitiçaria teria ocasionado a quase extinção da aldeia. Uma morte atribuída à feitiçaria forçou a emigração de uma família a fim de evitar represálias. Dessa forma, restou apenas uma família em Buridina, a do cacique Jacinto Maurehi. Foi ele quem criou os filhos de seu irmão já falecido, com a viúva deste irmão, Alice Coabiru. Para cumprir uma promessa feita à cunhada em seu leito de morte, ele decidiu empreender uma longa viagem até a Ilha do Bananal, buscando reunir os antigos habitantes e recompor a aldeia tal como ela fora em outras épocas. Durante dois anos, tempo aproximado que durou a viagem do cacique Jacinto, a aldeia de Buridina ficou desabitada.

Esse movimento praticamente idêntico que observamos em Buridina e entre os Xambioá faz parte de uma dinâmica faccional típica entre os Karajá. As mortes são sempre atribuídas a casos de feitiçaria e migraçóes se originam dessas acusaçóes. No entanto, numa situaçáo de contato com a daquelas frentes de expansão somadas ao declínio demográfico, essa emigração, que é uma movimentação populacional comum, toma o aspecto de um momento dramático de desaparecimento do grupo. No caso dos Xambioá, já não restava qualquer aldeia próxima onde se pudesse buscar exílio. No caso de Buridina, o caminho natural foi o de buscar os parentes dispersos nas aldeias da Ilha do Bananal.

\section{Período de intervençáo indigenista do SPI}

Nos anos 1940, a cidade de Aruanã era apenas um vilarejo e estava longe de conhecer a atual explosão do turismo. As terras que circundam a aldeia náo "pertenciam" a ninguém, e os Karajá podiam fazer suas roças em liberdade, sem dever explicações a quaisquer "proprietários”. Por sua vez, os Xambioá conheceram 
uma dispersão que levou toda a geração que atualmente tem mais de 50 anos a viver e trabalhar em cidades e fazendas até que eles fossem reunificados pelas mãos do mesmo SPI. É aqui que passamos a conhecer efeitos da experiência dos Karajá com a cidade.

A política praticada pelo SPI supunha uma inevitável futura integração dos índios ao contingente regional e, por isso, sua política territorial não incluía uma preocupação com a extensão dessas áreas no sentido de permitir a autossuficiência econômica. Segundo os Karajá de Buridina, no período de dois anos em que o cacique Jacinto desceu o rio em busca dos parentes para reconstituir a aldeia, o então inspetor do SPI, interpretando aquela dispersão como o "fim" da aldeia, teria loteado e vendido praticamente toda a área a eles destinada pelo Marechal Rondon. Era a partir daquele momento, portanto, que a cidade iria circundar a aldeia. O tempo do SPI é reconhecido como a época em que eles perderam a posse formal de suas terras.

Em 1959, provavelmente poucos anos após a reunificação, o censo do SPI indicava a presença de 40 Xambioás vivendo na nova aldeia junto ao posto. Acredito que tenha sido a época de maior baixa demográfica desse povo. Entre eles, o "tempo do SPI" é reconhecido como um tempo de fartura. Efetivamente, a referência à abundante roça é o motivo alegado por vários deles para o realdeamento do grupo. Lawari conta que o que motivou seu pai a retornar foi a presença de uma roça já formada em torno do posto.

Os funcionários do SPI tentavam limitar o contato dos Xambioá com os regionais, geralmente os barqueiros que passavam pelo Araguaia vendendo objetos, comprando farinha etc. Além disso, tal como entre os Xikrin analisados por Cesar Gordon (2006), os caciques tentavam controlar esse acesso aos batelóes, o fluxo de bens. Uma análise do controle do fluxo de bens pelas lideranças revelaria aspectos importantes da relação política karajá, mas excederia o espaço e o objetivo deste texto. Os batelóes faziam comércio geralmente levando produtos agrícolas, como farinha de mandioca, em troca de sal, cachaça, charque.

\section{O início da "mestiçagem"}

A reduçáo drástica das populaçóes das aldeias póe em jogo um dilema comum: a escassez de cônjuges potenciais. No período de maior baixa populacional em Buridina, havia sobrado uma única família extensa, a do cacique Jacinto. Colhi, entre diversos interlocutores, a impressão generalizada de que o grau ideal de afastamento dos cônjuges seria o casamento entre primos de segundo grau (a que se referem como "primo segundo"). Foi-me relatado um caso, por volta de finais dos anos 1970, da uniáo entre dois primos cruzados, da qual se originou uma 
criança. O cacique Jacinto, que era tio de ambos, expulsou o rapaz da aldeia pelo escândalo daquela união, nitidamente reconhecida como incestuosa. $\mathrm{O}$ rapaz passou alguns anos trabalhando em fazendas do Mato Grosso e posteriormente buscou seus parentes entre os Javaé da Ilha do Bananal, retornando a Buridina apenas depois da morte de seu tio Jacinto. Ao ser indagada sobre os casamentos mistos em Buridina, Jandira, uma senhora de aproximadamente 75 anos, afirma que já não havia quase ninguém na categoria de casável na aldeia: "casar com parente? É muito ruim! Casa com tori!"11 Entre os Xambioá, à escassez de cônjuges potenciais somava-se certa hostilidade nutrida entre duas facçóes: a família do capitão Manuel Achurê e os descendentes do capitão Tchekó. A convivência forçada entre duas facçôes que anteriormente viviam em aldeias distintas acirrava ainda mais os ânimos hostis. A atividade ritual, como as danças de aruanã e sobretudo a iniciação masculina, estava interrompida. Essa atividade ritual integradora costuma gerar uniôes matrimoniais, em especial a iniciação masculina, que requer a presença de uma aldeia visitante.

Disseram-me, no entanto, que os Xambioá eram frequentemente convidados a tomar parte nas festas da região, frequentada por trabalhadores das fazendas e dos povoados daquela porção do Baixo Araguaia. Os meus interlocutores xambioás são unânimes em indicar que o primeiro casamento com tori (não índio) foi o de Violeta. Ela própria me relatou o episódio. Contou que conheceu o marido num forró, festa típica do interior do Brasil. Seu pai era extremamente rígido e não admitia "namoro", então obrigou a filha a se casar com aquele tori que ela conhecera no forró. A outro interlocutor, também casado com tori, que me relatava a mesma história, indaguei: "e depois que ela se casou?" "Depois, a porteira já estava aberta." Procurou, com isso, dizer que os casamentos mestiços subsequentes eram inevitáveis.

Parece-me que a "porteira" estava apenas entreaberta. Outros casamentos entre Xambioá e tori ocorreram, sim, mas em meio a conflitos e disputas geracionais. Os mais velhos admoestavam esses casamentos. Em outro caso que me foi relatado, provavelmente no início dos anos 1980, uma Xambioá havia se casado com um tori, o que causava a reprovação de seus pais. Em uma viagem na boleia de um caminháo, os pais seguiam se queixando do casamento da filha. Ela teria se afastado deles e se jogado na estrada, com o caminhão em movimento, numa tentativa malsucedida de suicídio.

Como mencionei inicialmente, lideranças como o cacique Manuel Achurê acreditavam que aqueles casamentos levariam à extinção do grupo, à sua transformaçáo em tori, brancos. A preocupaçáo de Manuel Achurê parecia ser a de que, introduzindo-se os tori em seu convívio, as famílias passassem a ser estranhas 
umas às outras. Na fala de Dalva, "vocês não vão mais conhecer família”, ou seja, eles poderiam chegar a recusar os laços de parentesco.

Em Buridina, a fonte principal desses novos cônjuges foi a cidade de Aruaná, acrescida de regionais de fazendas não muito distantes da aldeia. Entre os Xambioá, essa fonte de cônjuges foi mais ampla - desde barqueiros, passando por trabalhadores de fazendas, até funcionários dos órgãos governamentais que atuavam na área (SPI e posteriormente Funai) e mesmo gente que conheceram em suas andanças no período da diáspora do grupo.

A partir dos anos 1980, uma família de Guarani Mbyá passou gradualmente a se instalar entre os Xambioá. Inicialmente apenas um casal, ao qual se juntaram alguns irmãos, primos, pais. Alguns desses Guarani prosseguiram em suas andanças, outros se fixaram entre os Xambioá. A chegada desse estoque extra de famílias indígenas parece ter sido bem recebida entre os Xambioá, e casamentos foram imediatamente arranjados entre jovens dos dois grupos.

Qual foi o efeito dessa intensa relaçáo aldeia-cidade? O efeito comum aos dois extremos do território Karajá foi o surgimento de uma nova categoria identitária, a de mestiço. Os filhos dos casamentos interétnicos são chamados de mestiços em português, e a língua Karajá não parece fornecer opção para essa categoria. ${ }^{12}$ Entre os Xambioá, indaguei a diversos informantes e percebi um consenso a respeito dos filhos das uniões entre Karajá e tori. Para eles, um filho de "puro" com tori seria um mestiço. O filho de mestiço com puro "puxa mais pro puro". O filho de mestiço com tori já teria "espalhado" demais o sangue e seria tori. Finalmente, um filho de mestiço com mestiço, para a grande satisfação dos avós, "puxa mais pro puro". Ao fazer as primeiras sondagens para o censo que realizava em cada aldeia e ao notar que essa categorização era importante, passei a incluí-la nas perguntas a serem feitas. Muitas vezes, registrei determinadas pessoas como tori para depois descobrir que eram filhas de mestiços com tori. Essa espécie de cálculo classificatório, para além de mostrar a percepção xambioá das unióes interétnicas, mostra que a mestiçagem já está presente em pelo menos três geraçôes (a primeira geração de mestiços chega agora à categoria de avós). Um dos poucos casais de "puros-puros" se mostrou orgulhoso de sua situação e acrescentou que era o único casal não apenas puro Karajá como puro iraru mahãdu, ou seja, Xambioá.

Em Buridina, esse cálculo é menos unânime que entre os Xambioá: se um mestiço casar-se com um tori e o filho dessa uniáo, por sua vez, casar com tori também, o neto já será tori. Ou seja, em Buridina, parece haver a necessidade de maior distância da "pureza” para que o indivíduo já não seja considerado índio. Outros cálculos identitários ocorrem entre os Xambioá para afirmar que a sucessiva união entre mestiços pode "apurar" o sangue, até que se elimine completamente 
o sangue de tori. Para cada "mistura", meu principal interlocutor xambioá tinha um exemplo disponível entre as crianças que estavam próximas. Para além do cálculo identitário, a categoria de mestiço será, em vários momentos, o principal combustível para alimentar as disputas faccionais internas às aldeias dos dois casos em tela.

Buridina é, poderíamos dizer, uma espécie de ilha-aldeia num mar urbano: cercada de cidade por todos os lados, exceto o lado do Rio Araguaia. Sua área, finalmente homologada, excluiu trechos importantes para suas referências sociais tradicionais. $\mathrm{O}$ local do antigo cemitério foi tomado pelos tori, em que máquinas e tratores escavaram, deitando ao rio as sepulturas e os ossos dos antepassados. No lugar do cemitério, vê-se um porto e um guarda-barcos. Descendo o rio, clubes e mansões foram erguidas sobre esse mesmo cemitério. A área indígena de Aruanã conta com três partes separadas. Essa primeira, inteiramente dentro do perímetro urbano da cidade, é a aldeia propriamente dita, onde se localizam as residências, a escola indígena, um barracáo de uso coletivo e o posto da Funai. Outra área, à jusante e afastada $3 \mathrm{~km}$ da primeira, é o chamado Aricá. Ali os indígenas podem fazer suas roças e residir. Abrigaram ali uma família da Ilha do Bananal e, ainda mais afastada, a casa isolada de uma das professoras indígenas e seu marido tori. A terceira e maior área fica do lado oposto do rio, já em terras mato-grossenses, numa área de várzea onde se podem fazer roças de ciclo curto e pescar num lago. Nessa área, alagável durante a cheia do rio, não há residências. As casas da aldeia de Buridina, todas de alvenaria, cedidas pela Funai, estáo dispostas da maneira tradicional, com duas portas, uma voltada para o rio, outra para a "rua" (espaço arruado entre as casas). Há duas fileiras de casas, totalizando 17 residências.

Aruanã é uma cidade turística. Nos períodos de cheia do Rio Araguaia (entre outubro e março, aproximadamente), mantém sua média de oito mil habitantes, talvez acrescidos de algumas dezenas nos finais de semana, quando as famílias que ali mantêm casas de veraneio se deslocam para passar alguns poucos dias. Em julho, mês de férias escolares e da maior baixa do rio, a cidade recebe um imenso afluxo de turistas. Todas as pousadas e casas de veraneio ficam lotadas, e as praias formadas pela baixa do rio, ocupadas por acampamentos particulares ou mesmo coletivos, organizados pela prefeitura ou pelas pequenas empresas que organizam eventos musicais naquelas praias. A cidade fica lotada e intransitável.

A fonte de renda, tanto da cidade quanto da aldeia, é esse turismo sazonal. Os meses que antecedem a alta temporada são marcados por obras de reforma e ampliaçáo nas casas para aluguel e nas pousadas da cidade. Enquanto isso, os Karajá estão avidamente confeccionando tudo o que podem fazer de artesanato: brincos, colares, pulseiras, anéis, miniaturas de objetos tradicionais (flechas, arcos, 
esteiras, remos, canoas), potes de cerâmica, bolsas de palha, souvenires como casinhas "indígenas" de cerâmica e até mesmo as litxokó, tradicionais bonecas de barro karajá. Toda essa miríade de objetos estará exposta num pequeno museuloja e à disposiçáo dos turistas de julho que queiram levar para casa alguma recordação de Aruaná.

Ainda durante a temporada, o espaço da aldeia se converte num estacionamento. É apenas durante aquele mês que os Karajá são incomodados e seu espaço é invadido por curiosos. Alguns relatam se sentir em uma jaula de zoológico, uma vez que os turistas ignoram as cercas e placas e chegam a andar por entre as casas, curiosos com aqueles "índios urbanos", tal como a profecia do cacique Jacinto, como "porco em chiqueiro".

Durante o ano, no entanto, a aldeia é um local pacato. Residentes de Aruanã vêm comprar peixe, o que garante alguma renda fora da temporada turística. Alguns fazem uma pequena roça nos fundos da casa, insuficiente para a subsistência, mas o bastante para suprir algumas necessidades (geralmente mandioca, milho, melancia, abóbora e algumas poucas frutas). Outras fontes de renda são serviços dentro da própria aldeia: professores, serventes da escola, auxiliares de saúde. Por último - e tendo um papel menor -, há quem busque emprego na cidade. Algumas moças chegam a procurar a prostituição. Não identifiquei nenhuma reprovação expressa quanto a essa alternativa econômica, nem com relação aos filhos dessas mulheres. O que havia de explícito era uma reprovação, por parte dos que se autodenominam "puros", à consequente mestiçagem.

Por ocasião da minha primeira estadia em Aruanã, em 2001, estava eleita como "vice-cacique" Valdirene e como cacique seu irmão, Beré (apesar do status oficial de vice, a liderança exercida por Valdirene era mais proeminente que a de seu irmão). Ambos são mestiços, filhos de Luiz, irmão do antigo cacique Jacinto. Nesta época estava bastante acentuada uma disputa entre os puros e os mestiços. Os dois irmãos, únicos mestiços em idade de participar da vida política da aldeia e com disposiçáo para tal, eram alvo das mais severas críticas por parte dos puros. Como fui introduzida na aldeia por Raul, um dos puros, só tive acesso às opiniôes e impressóes desta facção, sendo-me praticamente vetado o contato com a outra.

Para os puros, os mestiços seriam a maior fonte da contestação de seus direitos sobre a terra por parte daqueles que com eles as disputam: fazendeiros e donos de mansôes. Os mestiços seriam a justificativa do questionamento da autenticidade de Buridina enquanto aldeia karajá por parte dos fazendeiros da regiáo. O questionamento também viria de outros Karajás, aqueles da Ilha do Bananal, cuja aprovação lhes era tão cara. Renan, um dos meus interlocutores, habitante de Buridina, contou que, quando chegam às aldeias da Ilha para festas como o 
Hetohokã, os outros Karajás fazem troça deles: "lá vêm os tori de Buridina", o que para ele coloca em evidência o "problema" de serem uma aldeia com grande "mestiçagem".

As disputas faccionais em Buridina envolviam uma verdadeira discriminaçáo contra os ditos mestiços. Várias eram as razóes alegadas para esta atitude por parte dos puros. Uma delas era o questionamento, acima descrito, da "indianidade" de Buridina por parte de fazendeiros com os quais disputavam terras. Renan me relata uma reunião da Funai com fazendeiros em que se acertavam os detalhes da demarcação. Num dado momento, um dos fazendeiros teria dito: “...mas vocês [Funai] estão demarcando terra para sem-terra, não para índio?”

Outra razão para esta discriminação, que permeia a retórica da facção dos puros, é a aparente impossibilidade de os mestiços manterem as tradições orais, pois não ensinam seus filhos a falar inârybé, a língua dos Karajá, nem lhes contam as histórias antigas do grupo. A preocupação com o ensino da língua é latente e vários deles me demonstraram apreensão com o fato de as crianças mestiças não saberem falar o inärybé e, o pior, mesmo sabendo, se envergonharem de o falar.

Renan, que naquele contexto era definido como pertencente à facção dos puros, é dito, às vezes, "mestiço de Javaé com Karajá". Ele me dizia que seu pai era Javaé e, por isso, era bem-vindo entre os dois (Karajá e Javaé). Mais adiante, ao queixar-se das atitudes de Valdirene, um primo dele acrescentou: "ela tem de decidir o que ela é", como se o fato de ser mestiça a deixasse em uma posição dúbia, carregando uma identidade que poderia resvalar a qualquer momento, virando-se contra os Karajá por ela poder ser "bem aceita entre os dois". Por vezes encontrei declaraçóes explícitas de um desejo, por parte de alguns dos puros, de separar a aldeia, deixando os mestiços em Buridina e fundando uma aldeia "pura" no Aricá (área $3 \mathrm{~km}$ à jusante da aldeia). Essa segunda aldeia foi construída, mas sem a separaçáo pretendida anteriormente. Da segunda vez em que estive em Aruanã, em 2002, a situação estava bastante diferente. Desta vez os mestiços não eram mais caciques, não estavam em evidência, portanto as declaraçóes contra eles estavam muito menos frequentes.

Um mesmo "movimento migratório" se observará no outro extremo da terra dos povos inã. Os Xambioá estão divididos em três aldeias, não muito distantes umas das outras. A mais antiga, a aldeia chamada Xambioá, está no local onde havia sido erguido o posto do SPI nos anos 1950, agora em ruínas. Disposta à maneira tradicional, conta com duas fileiras de casas ao longo do rio e um arruado entre elas. Atrás delas, mais à montante, um largo campo de futebol acabou por definir a direção do crescimento das novas casas. Há quatro delas, além da escola, que se dispóem ao longo de um dos lados desse campo de futebol. 
André Toral relatou uma divisão de aldeia, nos anos 1980, motivada por disputa faccional idêntica à que presenciei em Buridina. Segundo Toral (1992), a disputa teria sido ocasionada pela intenção de um grupo que se autodesignava "puro" de se separar dos "misturados". Na atualidade, porém, a história de que se lembram para justificar aquela divisão é outra. Os Xambioá alegam que o motor da disputa fora um desentendimento sobre o destino do dinheiro da venda de madeira retirada de sua área. Nota-se que a justificativa pode alterar-se ao sabor das disputas políticas em maior evidência naquele momento.

A segunda aldeia, Kurehe, surgida daquela disputa dos anos 1980, está a cinco quilômetros à jusante da primeira. Uma das cheias do rio, em 2004, foi responsável pelo surgimento de uma terceira aldeia. Wari-Lytỹ é uma aldeia espacialmente atípica. Naquela ocasião, algumas famílias se recolheram para dentro da floresta, num local suficientemente alto para permanecer seco. Nesse movimento, construíram suas casas aleatoriamente, sem as referências espaciais típicas dos Karajá. ${ }^{13}$ No ano seguinte, um convênio entre Funai e Funasa deu a cada aldeia dez casas de alvenaria. Em reuniáo para decidir que formato teria a aldeia, concluíram que deveria ser linear, como uma aldeia karajá. Mas, ao invés de ser paralela, ela foi feita perpendicular ao rio, distando dele aproximadamente um quilômetro.

A população das três aldeias Xambioá soma quase trezentos habitantes, segundo dados de 2009. Uma boa parte da população adulta (maiores de 20 anos) e a totalidade da população mais velha (acima de 50 anos) viveu em algum momento de suas vidas em cidades. A língua nativa, o inârybé, quase não é ouvida nas três aldeias. Tornou-se praticamente uma marca de geração. Os poucos jovens que sabem falar são os que foram criados por seus avós ou, ainda, que passaram algum tempo em aldeias da Ilha do Bananal. A geração adulta tem atitude passiva com relação à língua (compreendem, mas não falam) e as crianças nem entendem nem falam. Essa perda da língua é atribuída a uma atitude de menosprezo e vergonha por parte das crianças. Não é viável determinar em que momento essa língua foi sendo relegada em benefício do português. De qualquer forma, em algum momento a presença do português tornou-se majoritária - seja pela presença de um número acentuado de tori, seja pela experiência da vida nas cidades da regiáo - a ponto de as crianças se envergonharem da língua falada pelos pais. A declaração de uma senhora é ilustrativa: "antigamente eu falava, pra ver se eles [os filhos] aprendiam. Mas eles ficavam mangando de mim, aí eu larguei". 


\section{Mestiços}

A despeito de uma atitude aparentemente hostil com relação aos mestiços, na prática, nos dois extremos do mundo karajá, não apenas os mestiços fazem parte do grupo, como a mestiçagem segue em curso. Se hoje em dia não há mais a necessidade de buscar cônjuges no exterior da comunidade, os mecanismos que possibilitaram o surgimento da categoria de mestiço continuam em pleno funcionamento.

A aldeia de Buridina perdeu uma parte considerável de sua área original para o território urbano de Aruaná. No entanto, foi lentamente reconstituída em meio àquela cidade, a despeito do seu crescimento e das baixas populacionais da aldeia. Os casamentos entre pessoas da aldeia e habitantes da cidade seguem ocorrendo.

Por sua vez, as aldeias xambioás foram formadas a partir de uma dispersão populacional completa e da experiência urbana de seus membros. A populaçáo só pôde se reconstituir devido aos casamentos com os tori, seja da vizinhança das fazendas, seja de cidades. As disputas faccionais que ocasionaram a dispersão das antigas aldeias e a cisão da primeira aldeia em duas seguem em curso. Não poucas vezes os Karajá que aí habitam saem em "exílio" para as cidades, para esperar os ânimos se amainarem. As hostilidades internas e a proximidade sanguínea são responsáveis por várias recusas de casamento ou mesmo por separações de casais já estabelecidos.

Entre os Xambioá, conversas veladas e fofocas anunciam um sempre iminente, mas nunca urgente, momento de "expulsão" dos tori, e uma recriminação com relação aos mestiços. De certa forma, a própria existência deles pareceria um empecilho ao reconhecimento, por parte dos órgãos governamentais, de sua "identidade" indígena. Há uma atitude permanentemente dúbia com relação aos mestiços e os tori que vivem entre eles. Reconhecendo que eles jamais expulsarão quem quer que seja da aldeia, tentarão eternamente questionar sua pertinência.

Registrei na aldeia xambioá um exemplo da dubiedade da atitude com relação aos tori. Um homem da aldeia Wari-Lytã, que já havia adquirido certa experiência com o processo de criação de uma associação indígena, ensinava a uma liderança da aldeia xambioá os passos para a oficialização da associação: a nomeação dos responsáveis pelos cargos (presidente, vice, secretário, tesoureiro), as atas, a assinatura de um advogado. Num determinado momento, lembrou-se de avisar que tomasse cuidado em náo colocar nenhum tori naqueles cargos. Ele havia cometido esse "erro" ao tentar registrar a associaçáo indígena de sua aldeia, sendo entáo advertido pelo advogado de que, se a associação era indígena, um tori não poderia ocupar nenhum dos cargos. Depreende-se daí que, na prática, os tori já estão suficientemente integrados à comunidade. Para ela, seria natural incluir 
um tori na associação indígena; entretanto, para o mundo administrativo, os tori ainda são Outros.

Outro episódio que ilustra a atitude dos órgãos do indigenismo oficial, representados individualmente por seus funcionários, é uma história ocorrida em Buridina, que me foi relatada pela protagonista. Célia é uma tori que há mais de trinta anos casou-se com um Karajá daquela aldeia. Ela morou com seu marido javaé em Canoanã, aldeia Javaé, aí vivendo vários anos. Separou-se daquele primeiro marido e, retornando a Buridina, casou-se com outro Karajá. Com outras mulheres de Buridina, Célia aprendeu a confeccionar a litxokó. Quando a aldeia foi beneficiada por um pequeno museu e loja de artesanato, ela passou a fazer as bonecas e outras peças artesanais para vender ali. Vendo aquilo, uma funcionária da Funai disse a ela que ela estava sendo "falsa", que estava "enganando" os turistas, porque ela era tori e vendia o seu artesanato como se fosse karajá. Constrangida, Célia passou muitos anos sem fazer as bonecas litxokó. Da parte dos Karajá, no entanto, jamais ocorreu um questionamento da legitimidade daquelas bonecas.

A situação particular do mestiço, tanto na aldeia, onde ele é um meio-aldeão, quanto na cidade, onde ele é um meio-cidadão, nos levaria a propor que sua "cidadania" - ou seja, sua condição de membro pleno de uma sociedade, que usufrua de todos os direitos - é permanentemente questionada. Como largamente exemplificado aqui, para os casos dos Xambioá e da aldeia buridina, os mestiços são fonte de disputas faccionais justamente por representarem a possibilidade de o caráter "étnico" do grupo ser questionada. E, no caso da recepçáo dos "serviços" que a eles se oferece como política indigenista, sua situação é duplamente questionada. Aparentemente, a existência do mestiço é responsável pelo questionamento de sua identidade, da "indianidade" do grupo. Parece haver um trabalho simbólico de "purificação" (Latour, 1994) necessário para o pleno acesso aos serviços oferecidos pela política indigenista.

Em sua revisão da literatura a respeito de "índios urbanos", Eduardo Nunes (2010a) desenvolveu essa imagem de uma "purificação" no sentido que Latour atribui ao termo. $\mathrm{O}$ autor parece sugerir que haveria, para o pensamento ocidental, uma associação de fundo entre cidade e "cultura" por um lado e aldeia e "natureza" por outro (Nunes, 2010a:18).

A pergunta que inicialmente animou a presente análise era: "a urbanização configura algum tipo de obstáculo à promoção da cidadania de grupos étnicos?” Depreende-se da descrição precedente que, nos casos que estou descrevendo e de que estou buscando aproximar, é justamente a característica "étnica” que permite o acesso a serviços "cidadãos". A verdadeira "cidadania ausente" é a do não étnico: o mestiço. E de que se trata, afinal os serviços oferecidos aos "cidadãos étnicos"? 


\section{Os "serviços": o que são, como "funcionam"}

Para realizar uma análise que dê conta das categorizaçóes nativas, é necessário fundamentalmente nos perguntar: afinal, por que a demanda indígena por serviços? Por que a escola, a saúde, por que sua adesão, tão prontamente, aos programas de "resgate da cultura"?

No contato de Rufino T. Segurado com o cacique Carô reportado no início deste artigo, o cacique mostra-se propenso a receber a empresa colonizatória, o que foi interpretado por Donahue como um desejo pelos "bens" dos brancos. Sua posterior recusa significaria a recusa dos intermediários, ou seja, os próprios brancos. Alencastre (1979), em seus Anais da província de Goiás, relata que, no início do século XIX, os Xambioá teriam enviado emissários à capital da província pedindo para serem beneficiados por um aldeamento. O que queriam os Karajá? $\mathrm{O}$ que significa sua demanda por coisas dos brancos?

Tanto em Buridina quanto entre os Xambioá, a introdução da escola é relatada pelos nativos como um antigo desejo de uma liderança que já faleceu. Os caciques karajás demonstravam seu prestígio a partir do que podiam obter, ou controlar, dos brancos. Nesse caso, "presentes de branco", tais como escola, saúde ou "resgate da cultura”, podem ser acionados, demandados e, por que náo, repelidos ao sabor das disputas faccionais.

A escola da aldeia Buridina, segundo Kari, foi idealizada por seu tio, o cacique Jacinto Maurehi. A escola foi estabelecida nos anos 1980 e consolidada nos anos 1990, passando recentemente à responsabilidade do Estado. Na atualidade, a escola tem disponíveis desde a alfabetização até a quarta série do ensino fundamental. No que concerne a seu status de "específica e diferenciada", ${ }^{14}$ a escola conta com aulas de inârybé, para fins de "resgate da língua" e aulas de artesanato indígena. No entanto, descrever como a escola "funciona" é também descrever suas "funçôes", não apenas aquelas explícitas ou esperadas, mas as socialmente efetivas.

Como por toda parte, a escola karajá é ao mesmo tempo menos e mais do que uma escola náo indígena. Cada cargo proporcionado pela escola, como merendeira, zeladora, professores, diretor, é decidido em reunióes nas quais concorrem todas as armas da lógica faccional. Para além do salário que, naturalmente, é aceito de bom grado, trata-se de marcar presença competindo pela predominância no cenário político da aldeia.

Em março de 2008, na aldeia de Buridina, a escola era o cenário preferido para a disputa política, menos que a disputa "puros" versus "mestiços". Kari, que foi durante anos a professora de inárybé e de artesanato, havia perdido seu posto por ter baixa formaçáo escolar, depois das reformas que transferiram a responsabilidade da escola para a Secretaria de Educaçáo do estado. Em disputada 
reunião no ano anterior, ela havia sido eleita a diretora da escola, para júbilo de sua facção, que se queixava de ser ela discriminada por não ter muito estudo. Ao menos, não tanto quanto seu oponente, Albertinho, que tem formação de magistério. Naquela mesma reuniáo, esse professor foi encaminhado à classe préescolar, na qual seus anos de formaçáo de nada valeriam.

Posteriormente, os professores que assumiram as antigas funções de Kari passaram a ser criticados por não "levar a sério" as aulas. Além disso, havia uma queixa generalizada de que as aulas da escola eram fracas e os alunos não eram submetidos às mesmas exigências nem tinham a disciplina de um aluno de escola de tori.

No intuito de resolver o caso, foi feita uma reuniáo do Conselho Escolar. Indaguei quem seriam os participantes do tal conselho e se eles tinham alguma ligação direta com a escola. Foi-me explicado que não era necessária uma ligação com a escola: "quem tiver interesse, quem quiser, pode participar". Ao listar os integrantes do conselho, percebi que se tratava de um retrato fiel das aspiraçóes políticas da aldeia. Naquele momento, ele tomava o aspecto de um tribunal em que seriam julgados os maus professores. Curiosamente, os "acusados" não compareceram à reunião. Naquela ocasião, nada ficou definitivamente decidido, mas a palavra "expulsão" soou no ar.

Aparentemente, o Conselho Escolar se assentou perfeitamente na dinâmica da disputa faccional. Ele não implica cargos nem salários, o que afasta a hipótese imediatista do desejo por bens dos brancos. Por fim, se uma atitude drástica como a expulsão de um professor vier a ser decidida, ela virá pelas mãos impessoais do Estado, na figura da "secretaria", isto é, da Secretaria Municipal de Educação. Dessa forma, a disputa segue seu curso sem que as relaçóes pessoais fiquem visivelmente abaladas, ainda que, "invisivelmente", estejam deterioradas. Se a escola funcionar, ou seja, se efetivamente se prestar à educação formal das crianças na aldeia, tanto melhor, mas não parece ser essa a preocupação central. Se ela não funcionar, estará igualmente alimentada a máquina de reprodução da política faccional da aldeia.

Há alguns anos os Xambioá fizeram acordos com a Fundação Cultural da Universidade Federal do Tocantins, com o propósito de um programa de "resgate da cultura”, que lhes garantiu auxílios diversos. Desde então, têm se esforçado por manter um calendário de realização de um ritual e de "danças típicas", geralmente em datas comemorativas, a fim de atrair a atenção dos tori que possam vir a se tornar aliados políticos (sobretudo no Dia do Índio e aniversário da aldeia). O ritual que realizam é o Karalahu, um ritual de oferendas de comida a uma entidade espiritual, o Karalahu, que encarna o espírito de um guerreiro kayapó. 
Segundo os Xambioá, o Karalahu jamais deixou de ser realizado, mesmo nos períodos de maior baixa demográfica. Chamo a atenção para três aspectos que podem ter levado à execução preferencial desse ritual. A execução do Karalahu não exige nenhum conhecimento xamanístico. Ao espírito é atribuída a capacidade de se apoderar da máscara sem o intermédio de um especialista. Ademais, essa representação não oferece muito "perigo". Os Xambioá temem voltar a executar os rituais tradicionais porque eles "trazem muito feitiço" e, se não houver xamãs com o poder considerado satisfatório para aplacar aqueles espíritos, pode-se perder o controle sobre a situação. Por fim, há motivações particulares. O Karalahu é o único ritual executado exclusivamente pelos Xambioá. Ele é desconhecido nas aldeias da Ilha do Bananal, e vários Xambioá não hesitaram em me contar, orgulhosos, que os Karajá "de cima” (das aldeias da Ilha ou mais à montante), ao visitá-los, ficaram curiosos e queriam enviar seus filhos para aprender a executá-lo.

Portanto, o ritual Karalahu seria, entre outras coisas, uma forma de se afirmar perante os outros Karajá, mostrando algo peculiar aos Xambioá. Ao mesmo tempo, eles mantêm algum reconhecimento de sua "etnicidade" aos olhos dos seus aliados tori (Funai e a então Funasa, atual Sesai). Há sempre uma ameaça, repetida por algumas lideranças, à continuidade da assistência prestada pelas agências governamentais. Uma frase repetida é a de que "o pessoal anda dizendo que essas aldeias, assim, que não tiverem mais nada da cultura, a Funai não vai ajudar mais não".

Além do Karalahu, os Xambioá têm se esforçado em realizar o que chamam de "danças típicas". Animados por um dos professores de inãrybé, reúnem-se aperiodicamente, pintam-se e, aqueles que o possuem, se paramentam com um cocar tradicional, o Rahetô. A isso eles chamam de resgatar a cultura.

O uso do termo "cultura" pelos Xambioá é curioso e merece uma contextualização etnográfica. As casas de alvenaria doadas pela Funasa são todas compostas de dois quartos, uma sala, uma área de serviço nos fundos e uma generosa varanda à frente. A cobertura do interior das casas é de tijolos, mas a cobertura da varanda é de palha. Ao me mostrar a casa, um professor de língua indígena aponta para a palha do telhado da varanda e diz: "isso aqui, isso é a cultura indígena. Não pode deixar de ter. Senão, descaracteriza” (ênfase minha).

Durante minha estadia em Wari-Lytã, houve dois momentos em que os homens se paramentaram e dançaram cantando cantigas tradicionais. A maioria não sabe falar a língua indígena, mas decorou a canção. Havia um clima de ansiedade com relação às primeiras danças. Um semicírculo de cadeiras foi formado, onde se sentaram as mulheres com seus bebês, circundados pelas crianças. Num outro semicírculo, os homens se preparavam para dançar. Eles estavam muito tímidos 
e, a uma gargalhada feminina causada por conta das estripulias de dois meninos pequenos, os homens reagiram retornando ao "seu" semicírculo, envergonhados, acreditando que as mulheres riam deles. Kurikalá, professor de inãrybé e animador do evento, os impeliu a dançar na frente delas e a continuar, até que se esgotasse o estoque de cançóes que eles sabiam.

Para aquela ocasiáo, alguns homens haviam feito pinturas tradicionais em seus corpos com jenipapo e vestido os paramentos que acompanham essas danças (braceletes e perneiras com franjas de algodáo pintado de vermelho). Dois deles portavam o Rahetó, cocar Karajá trazido da Ilha do Bananal, o que causava admiraçáo nos outros. Um deles declarou, satisfeito, que estava "vestindo a cultura".

Algumas semanas mais tarde, o mesmo grupo foi executar essas danças, dessa vez na aldeia Kurehe. Essa segunda execução foi bem mais breve, em meio a uma algazarra de crianças. Outras tentativas de iniciar a dança foram feitas naquela aldeia, mas os dançarinos ficavam nitidamente constrangidos. Nos dias seguintes, escutei repetidas queixas sobre a população de Kurehe. Ela é conhecida pejorativamente como "aldeia de branco", devido ao grande número de tori e mestiços que ali habitam. Para eles, ali ninguém "se interessa pela cultura”.

Analogamente à educação na escola em Buridina, aqui não é possível dizer se o "resgate da cultura" realmente funciona. Suspeito que a lógica nativa náo esteja interessada necessariamente em sua estrita "funcionalidade", ou sua capacidade de atingir determinado fim. É possível dizer, no entanto, que tal resgate é, ele também, um dos combustíveis da disputa faccional - nesse caso, a disputa entre as aldeias -, ainda que se dê sobre um ritual que, segundo os Xambioá, jamais deixou de ser realizado.

\section{Culto à carga e seus similares}

Em 1991, em sua etnografia sobre as comunidades nativas do Baixo Urubamba, na Amazônia peruana, Peter Gow chamava atenção para o porquê do interesse indígena pela escola:

no Baixo Urubamba, a presença de uma escola numa comunidade a define como um casario legítimo, uma aldeia legítima. Isto é verdade não apenas para os nativos, mas para os agentes do estado em Atalaya: estes agentes não visitam, reconhecem ou recenseiam assentamentos sem escola. [...] No nível do simbolismo espacial, o prédio da escola é central para a própria comunidade: ele é quase que invariavelmente a maior construção da comunidade. É o local não apenas de instruçáo formal, mas de festas e reuniôes da Comunidad Nativa e dos eventos religiosos cristáos. Onde há uma escola, as pessoas são, por definição, não "moradores da floresta" [algo como "selvagens"] (Gow, 1991:230, tradução minha). 
Para ilustrar a importância da escola, Peter Gow conta o caso de uma comunidade chamada Kinkón, desprovida de escola. Ela era formada por trabalhadores associados a um determinado patrão e por alguns índios Campa que a eles se ajuntaram. Algumas crianças dali frequentavam a escola de outras comunidades. Ao perguntar sobre esta comunidade, Gow tinha como resposta que não existia comunidade ali, que eles eram apenas "moradores da floresta" ("viven en el monte así nomás"). Certa feita, Gow foi convidado por um de seus compadres a visitar aquela aldeia. Depois de muito caminhar na floresta e subindo a montanha, chegaram à aldeia, composta de duas clareiras. Seu compadre mostrou as casas e, finalmente, uma casa bem mais robusta, grande. Para sua surpresa, foilhe explicado que aquela era a casa da escola: "era uma bela construção contendo cadeiras, carteiras que visivelmente haviam sido feitas com muito esmero" (Gow, 1991:230). Seu compadre explica que eles haviam feito tudo, mas ninguém vinha até ali para lecionar às crianças. Por isso as crianças viviam dispersas, tinham de ir às outras comunidades para frequentar a escola: "nada poderia expressar melhor o que é ser uma 'verdadeira aldeia' no Baixo Urubamba” (Gow, 1991:230).

Esse episódio pareceu-me evocar praias muito mais distantes. Entre o final do século XIX e meados do século XX, um curioso fenômeno ocorreu na Nova Guiné e em outras ilhas do Oceano Pacífico, intensificado após o final da Segunda Guerra Mundial. Povos nativos daquelas ilhas construíram, por iniciativa própria, improvisadas pistas de pouso e, às vezes, em madeira, pequenas imitaçóes de aeronaves que deixavam à beira daquelas pistas. Alguns avióes em pane muitas vezes de fato recorriam àquelas pistas de pouso. Antes que fosse banalizado ou excessivamente generalizado por pesquisas antropológicas, esse fenômeno foi conhecido por Cargo Cult, ou o Culto à Carga (Lindstrom, 1993). Na expectativa de que os aviôes, que outrora traziam cargas valiosas, tornassem a aparecer, os nativos literalmente preparavam o terreno para tornar isso possível. ${ }^{15}$

O fenômeno descrito por Peter Gow na aldeia Kinkón parece evocar a armadura conceitual do culto à carga. Ignorados da política indigenista oficial, os habitantes daquela diminuta aldeia se esmeraram em construir uma escola. Boa madeira, estrutura firme, belas carteiras e cadeiras. Construindo a estrutura física (a forma) da escola, aquela comunidade nativa manifestava sua esperança de que ela fosse preenchida pelo conteúdo que se supóe vir a reboque. Como vimos, muito mais que instruçáo formal, a escola no Baixo Urubamba seria o reconhecimento social daquela aldeia. Ou, se quisermos, a "afirmação" de sua identidade.

Como entre os Piro do Baixo Urubamba, os Xambioá do Baixo Araguaia são gente "de sangre mezclada". O caráter "étnico" daquela comunidade é frequentemente questionado não apenas pelos agentes da política indigenista, 
mas por aqueles que cujo apreço lhes é tão caro, os Karajá da Ilha do Bananal - e, como foi aqui descrito, entre eles mesmos, seus parentes da aldeia. "Vestir a cultura" (sic) na forma de danças, da realização de um ritual que se encaixa em suas aspirações, na palha do telhado de suas casas ou na periódica preparação de pratos considerados "típicos", não é apenas uma fantasia engraçada para satisfazer os tori. É, diríamos, a performação de uma espécie de "cultura cult" (perdoado o cacófato), um culto à cultura. Como o school cult observado entre alguns nativos do Baixo Urubamba, nosso culto à cultura parece-me representar a esperança, por parte dos Xambioá, de ter reconhecida sua identidade, a despeito de sua mestiçagem, na espera de que os "presentes de branco", não necessariamente materiais, venham preencher de conteúdo os espaços que a armadura "cultural" deixou.

Ao elaborar essa interpretação pela primeira vez, tive receio de que fosse uma comparação exagerada. Eu então ignorava a pertinente contribuição de Roy Wagner, que também lança mão da ideia de cargo cult para ilustrar a "invenção da cultura”. Nos termos de Wagner, seria pertinente dizer que em diversos momentos é disso que se trata quando os Karajá buscam legitimidade em sua indianidade.

\section{Invenção da cultura}

Roy Wagner considera a antropologia uma abordagem informada por um objeto construído ocidentalmente, a "cultura". Mas não é qualquer tipo de construção. Trata-se de uma "invenção". A cultura seria uma construção que auxilia o entendimento de um povo que não conceberia, a priori, a noçáo de cultura para si mesmo. Wagner pesquisou junto ao povo Daribi, da Nova Guiné, que, como muitos da região, conheceu o fenômeno do culto à carga:

olhamos para a carga dos nativos, suas técnicas e artefatos, e a chamamos de "cultura", ao passo que eles olham para nossa cultura e a chamam de "carga" [...]. Já que "carga", assim como "cultura", é um termo de mediação entre diferentes povos, a relação que ele encarna torna-se aquela dos melanésios com a sociedade ocidental. O fato de que "carga" e "cultura" metaforizam a mesma relação intersocietária, conquanto o façam em direçóes opostas, por assim dizer, torna-as efetivamente metaforizaçóes uma da outra. "Cultura" estende a significância da produção mútua e das relaçôes humanas para os artefatos manufaturados: cada conceito usa o viés extensivo do outro como seu símbolo (Wagner, 2009:101).

O autor sugere, enfim, que o culto à carga seria uma espécie de contrapartida interpretativa da antropologia: 
fica claro do que se expôs que os devotos de ambos os conceitos, carga ou cultura, não conseguem apreender facilmente o outro conceito sem transformálo no seu próprio, mas também fica claro que essa característica não é exclusiva dos seguidores do culto ou dos antropólogos, que todos os homens projetam, provocam e estendem suas ideias e analogias sobre um mundo de fenômenos intransigentes (Wagner, 2009:106).

A verdadeira cidadania manquée pode não estar no étnico, mas no mestiço. É a figura do mestiço que parece impedir o étnico de alcançar a cidadania (urbana). É a urbe que impede o mestiço de ser reconhecido como um cidadáo étnico.

\section{Dançando cacofonias}

Nos casos que estou buscando descrever, a categoria de mestiço passou a ser central, em determinado momento, na definição do acesso à política indigenista. E foi justamente nela que vim a encontrar categorias identitárias: a categoria de mestiço, definida em oposiçáo tanto ao "branco" (ou tori) quanto ao "índio".

Essa não é a única fonte de argumentos para as disputas faccionais, mas uma que estava em evidência quando eu registrava minhas primeiras impressóes em Buridina. Ela é particularmente relevante para o interesse deste artigo por se articular com as demandas indígenas pelos "serviços" que lhes são oferecidos como política indigenista.

Se o "homem é o xamã de seus significados", como diz Wagner (2009:106), é possível pensar numa imagem da mestiçagem criada pelos nativos como uma espécie de antropologia reversa. Esta imagem me foi fornecida por Renan, da aldeia Buridina. Em nossas intermináveis e ricas conversas, certa vez ele me perguntou o que queria dizer a palavra "caboclo", quem afinal era essa gente. Expliquei que era um termo comum na Amazônia para designar populaçóes que não tinham um estilo de vida como o de branco, mas que também náo eram índios. Completei dizendo que, às vezes, apenas a aparência física de indígena era suficiente pra chamar alguém de caboclo. Renan riu um pouco da situação do "caboclo" e também da palavra, que lhe soava engraçada. Comentou que em Buridina eles poderiam acabar virando, também, uma espécie de caboclos. E me brindou com essa imagem significativa:

quando chega a época do veráo, aqui em Aruaná, a cidade fica muito cheia. Muito cheia mesmo, não dá nem pra andar. $\mathrm{O}$ pessoal acampado aí na praia, pescando, nadando no rio. Aí, tem uma coisa meio ridícula, você já viu? Umas caminhonetes grandonas, você já viu umas que a caçamba sobe? Não? Pois é, é uma coisa esquisita. Aí vem um, estaciona ali na praça e coloca uma música bem alta, fica dançando com a namorada lá em cima na caçamba. Não sei, 
uma moça ali. Aí vem outro, parece que é pra competir, né?, e coloca outra caminhonete do lado, com outra música. Não sei como é que eles aguentam aquele barulho. Cada um aumenta o som o que pode e fica um pessoal ali, dançando. Aí nós ficamos olhando aquele negócio. Não dá pra entender. Esse pessoal tá dançando o quê? Não dá pra escutar nenhuma música, eles ficam dançando sem saber que música é. Pois é! Nós aqui estamos assim, entendeu? Tem o tori, tem o inã, mas aqui em Buridina, ninguém sabe o que é, você entendeu? Que música a gente tá dançando?

Definir-se a si mesmo, definir a aldeia na cidade, o ethnos na urbe, para Renan, seria algo como dançar aquela cacofonia. Buscando compreender o "caboclo", um mestiço, Renan terminou por criar uma bela imagem de sua "dança".

Se as sugestóes expostas ao longo deste artigo não chegam a ser esclarecedoras, o que não foi exatamente sua pretensão, espero ao menos que elas tenham possibilitado um esclarecimento etnográfico do surgimento da categoria mestiço, fruto da vivência com o "mundo dos brancos" e algumas de suas consequências.

Recebido em: 29/11/2016

Aprovado em: 02/05/2018

Helena Moreira Schiel é professora assistente na Universidade Federal do Oeste do Pará, em Santarém, e doutoranda em antropologia social na École des Hautes Études en Sciences Sociales, em Paris. Tem interesse em etnologia indígena, antropologia da guerra e cultura material karajá. Contato: helenaschiel@gmail.com. 


\section{Notas}

1. A versão inicial deste artigo foi feita em forma de ensaio para um concurso da ABA/Ford. Disponível em: http://www.abant.org.br/conteudo/001DOCUMENTOS/ Informativo/info2008.pdf.

2. Inã é a autodesignação de três grupos indígenas do Brasil Central: Xambioá, Karajá e Javaé. Em trabalhos anteriores me referi a eles como "Karajá" de modo geral e falando dos três grupos como "subgrupos", como era praxe na literatura. Entretanto, recentemente alguns Javaé passaram a considerar ofensivo ser chamados de "subgrupo" dos Karajá, como foi registrado na literatura, em especial, pelos excelentes trabalhos de Patrícia Rodrigues $(2003,2012)$. Sigo, então, a modificação aceita na literatura. É importante fazer notar, entretanto, que este ponto é controverso entre os Javaé. No período em que fiz pesquisa na aldeia javaé de Canoaná, diversos habitantes me declararam ser indiferentes a essa classificação, porque eram todos considerados inã. Esses marcadores étnicos, quando diante das políticas indigenistas, acionam mecanismos de disputa faccional. Um exemplo é o termo para o grupo Xambioá. Corruptela da expressão "povo amigo" (ixã biowa), ele variou entre os povos que se autodenominam inã e vivem tradicionalmente às margens do Rio Araguaia e no interior da Ilha do Bananal. Sua língua comporta quatro dialetos mutuamente compreensíveis.

3. Não se trata, portanto, de um trabalho voltado para as transformaçóes corporais ou para a inclusão da experiência de intelectuais indígenas abrigados no espaço acadêmico, como tem sido praxe mais recentemente - experiência importante que, entretanto, eu não teria condições de analisar com os dados de que disponho hoje.

4. Tori é o termo utilizado para se referir aos não índios. É usado alternativamente ao termo "branco", embora com menos frequência.

5. Os dados aqui apresentados foram obtidos em momentos diferentes. Estive em Buridina entre 2000 e 2001, retornando em 2007 e 2008, totalizando dois meses de observação de campo. Os dados xambioás se baseiam em oito meses de pesquisa, realizada entre 2006 e 2009. Agradeço entusiasticamente a leitura e o diálogo com Eduardo Nunes, que conheceu duas versóes iniciais deste artigo.

6. Os Karajá concebem seu universo como composto de três patamares sobrepostos. A humanidade teria ascendido do patamar mais baixo (o mundo subaquático) para o patamar intermediário (o mundo terrestre, onde vivem atualmente), ascensão completada por alguns heróis em tempos mitológicos e poderosos xamás de tempos históricos, que alcançam o terceiro patamar (o mundo celeste) após a morte.

7. Segundo os Karajá, o nome da cidade seria uma corruptela do termo em inãrybé (a língua karajá) Biri-Tãkiná (Biri = periquito, Tãkiná = poleiro). Num primeiro momento, eu havia registrado o termo como tahiná, que quer dizer estrela. Agradeço a Eduardo Nunes por me chamar a atenção para a sutileza. 
8. Paul Ehrenreich integrou a segunda expedição de Karl von den Steinen à regiáo do Rio Xingu (1887). Responsável pela coleta de dados de antropologia física de von den Steinen, Ehrenreich foi o primeiro etnógrafo que se ocupou dos Karajá.

9. Provavelmente Xikrin, chamados de Karalahu pelos Karajá.

10. Há arquivos na Prelazia da cidade de Conceição do Araguaia (PA) que podem elucidar as razões da surpreendente baixa demográfica dos Xambioá nesses sessenta anos. Outra fonte de informação é o Mensageiro do Santo Rosário, periódico publicado por padres dominicanos que circulou de 1898 a 1960. Seus arquivos estáo guardados pelos padres dominicanos em Uberaba (MG). Não tive acesso a nenhuma das duas fontes para esclarecer esse período, em que há poucas fontes históricas ou etnográficas adicionais (Barrado Barranquilla, 1997:535).

11. Um trabalho posterior a este (que lançou máo dos rascunhos do artigo que ora apresento) forneceu uma interpretação bastante diversa da opção pelo casamento mestiço. Diversamente do que propus, Nunes $(2009,2010 \mathrm{~b})$ sugere tratar-se de uma "escolha".

12. Meu uso dos termos "mestiço" e "mestiçagem" são apropriaçôes imediatas do discurso nativo. O termo "branco" é usado alternativamente ao termo tori para designar genericamente os não índios, independentemente da cor da pele.

13. Linhas de casas ao longo do rio. Em aldeias grandes com vida ritual completa, uma "casa dos homens" é construída na altura mediana daquela fileira de casas residenciais, afastada delas e voltada para a mata. O pátio formado diante dessas casas é o local das danças e dos rituais.

14. "Os Povos Indígenas têm direito a uma educação escolar específica, diferenciada, intercultural bilíngue/multilíngue e comunitária” (Funai, s.d.).

15. O fenômeno do culto à carga é bastante mais complexo do que essa minha breve descrição. Tem origens no início da colonização europeia naquelas ilhas, a partir dos navios que pareciam trazer valiosas cargas. Ao longo dos séculos XIX e XX, mesclouse às ideias cristâs de salvação a ponto de a palavra "Deus", no pidgin falado na Nova Guiné, significar "a fonte da carga". A classificação de fenômenos sociais como cultos à carga passou a ser tão generalizada na antropologia daquela região que o modelo teórico foi dissolvido como inconsistente para a maioria dos casos. Para maiores detalhes, ver Lawrence (1964) e Lindstrom (1993). Tem sido retomado, no entanto, por Roy Wagner em outra formulação, como se verá adiante.

\section{Referências}

ALBERT, Bruce. 2002. "O ouro canibal e a queda do céu: uma crítica xamânica da economia política da natureza (Yanomami)". In: Alcida Ramos \& Bruce Albert. Pacificando o branco: cosmologias do contato no noroeste amazônico. Sáo Paulo: Ed. Unesp; Imprensa Oficial do Estado. pp. 239-274. 
ALENCASTRE, José Martins Pereira de. 1979. Anais da Provincia de Goiás. Brasília: Ipiranga. Publicado originalmente em 1865.

ANDRELLO, Geraldo. 2006. Cidade do Indio. Transformaçóes e cotidiano em Iauaretê. São Paulo: Ed Unesp/ISA/Nuti.

BALDUS, Herbert. 1948. "Tribos da bacia do Araguaia e o Serviço de Proteção aos Índios". Revista do Museu Paulista, 2(n.s.):137-169.

BARRADO BARQUILLA, José. Los dominicos y el nuevo mundo: siglos xvIII-XIX. Actas del V Congreso Internacional Querétaro (México). Salamanca: San Esteban.

BONILLA, Oiara. 2000. Reproduzindo-se no mundo dos brancos: estruturas Karajá em Porto Txuiri.

CARDOSO DE OLIVEIRA, Roberto. 1972. O índio e o mundo dos brancos. São Paulo: Pioneira.

1978. A sociologia do Brasil indígena. Rio de Janeiro: Tempo Brasileiro.

CASTELNAU, Francis. 1949. Expediçâo às regióes centrais da América do Sul. São Paulo: Companhia Editora Nacional.

COUDREAU, Henri. 1897. Voyage au Tocantins-Araguaya. Paris: A Lahure.

DONAHUE, Goerges R. 1982. A contribution to the ethnography of the Karaja indians of Central Brazil. Tese de doutorado, University of Virginia.

EHRENREICH, Paul. 1948. "Contribuições para a etnologia do Brasil". Revista do Museu Paulista, 2(n.s.):7-135. Publicado originalmente em 1891.

FUNAI (Fundação Nacional do Índio). Educação escolar indígena. Disponível em: www. funai.gov.br.index.php/educacao-escolar-indigena. Acesso em: 26/01/2018.

GORDON, Cesar. 2006. Economia selvagem: ritual e mercadoria entre os índios XikrinMebengôkre. São Paulo: Ed. Unesp; Nuti; ISA.

GOW, Peter. 1991. Of mixed blood: kinship and history in Peruvian Amazonia. Oxford: Clarendon.

LASMAR, Cristiane. 2005. De volta ao Lago do Leite. Gênero e transformação no Alto Rio Negro. São Paulo: Editora da Unesp/ISA/Nuti..

LATOUR, Bruno. 1994. Jamais fomos modernos. Rio de Janeiro: Editora 34.

LAWRENCE, Peter. 1964. Road belong Cargo: a study of the Cargo Movement in the Southern Mandang District, New Guinea. Manchester: Manchester University Press. 
LINDSTROM, Lamont. 1993. Cargo cult: strange stories from Melanesia and beyond. Honolulu: University of Hawaii Press.

NUNES, Eduardo. 2009. A cruz e o itxe(k)ó: mestiçagem, mistura e relação entre os Karajá de Buridinan(Aruanã - GO). Monografia de graduação. Brasília: Universidade de Brasília.

. 2010a. "Aldeias urbanas ou cidades indígenas?” Espaço Ameríndio, 4(2):9-30.

. 2010b. "O pessoal da cidade": o conhecimento do mundo dos brancos como experiência corporal entre os Karajá de Buridina” in: Marcela COELHO DE SOUZA \& Edilene COFFACI DE LIMA. (Orgs.) Conhecimento e cultura. Práticas de transformação no undo indigena. Brasília: Athalaia. Pp. 205-228.

2012. No asfalto não se pesca. Parentesco, mitura e transformação entre os Karajá de Buridina (Aruanã - GO). Dissertação de Mestrado. Universidade de Brasília

PÉTESCH, Nathalie. 2000. La pirogue de sable: pérénité cosmique et mutation sociale chez les Karajá du Brésil Central. Louvain; Paris: Peeters; Selaf.

RIBEIRO, Darcy. 1970. Os índios e a civilização. Rio de Janeiro: Civilização Brasileira.

RODRIGUES, Patrícia 1993. O povo do meio: tempo, cosmo e gênero entre os Javaé da Ilha do Bananal. Dissertação de mestrado, Universidade de Brasília.

2005. "De corpo aberto: o poder tecnológico dos não-índios no mito e na cosmologia Javaé”. Habitus, 3(1):125-143.

. 2008. A caminhada de Tynyxiwe: uma teoria Javaé da história. Chicago: Universidade de Chicago.

SCHADEN, Egon. 1969. Aculturação indígena. São Paulo: Pioneira.

SEGURADO, Rufino Theotonio. 1848. "Viagem de Goyaz ao Pará". Revista Trimensal de História e Geographia, X(2):178-212.

TORAL, André Amaral de. 1992. Cosmologia e sociedade Karajá. Dissertação de Mestrado, Museu Nacional, Universidade Federal do Rio de Janeiro.

VELHO, Otávio 1972. Frentes de expansão e estrutura agrária. Rio de Janeiro: Zahar.

WAGNER, Roy 2009. A Invenção da Cultura. São Paulo: Cosac\&Naify. 


\section{Resumo}

Este artigo reflete sobre as condiçóes de cidadania entre os índios Karajá a partir de sua experiência urbana e interétnica. Compara a situação dos dois extremos do território karajá: o subgrupo Xambioá, mais ao norte, e a aldeia Buridina, mais ao sul de seu território, ao longo do Rio Araguaia. Os casamentos interétnicos deram origem à classificação identitária de "mestiço". Argumenta-se que a condição dúbia do mestiço o impede de acessar plenamente sua "cidadania" na forma dos serviços fornecidos pela política indigenista.

Palavras-chave: etnologia indígena, relaçóes interétnicas, índios Karajá, cidadania, mestiçagem.
This article approaches the citizenship conditions of Karajá Indians based on their interethnic and urban experience. It compares the situations of two extremes of the Karaja territory: the Northern subgroup, Xambioá, and the Southern village, Buridina, along Araguaia River. Interethnic marriages originated the mestizo identity classification. It is argued that the dubious condition of mestizo denies him full access to citizenship in the form of services provided by the indigenous policy.

Key-words: ethnology, interethnic relations, Karajá indians, citizenship, métissage. 